\title{
Sığır gübresinin pamuk solgunluk hastalığı (Verticillium dahliae Kleb.) ile verim ve verim parametrelerine etkisi
}

The effect of cattle manure treatments on cotton Verticillium wilt disease (Verticillium dahliae kleb.), yield and yield parameters

\author{
Pınar SAĞIR ${ }^{1}$ (D) Aysel BARS ORAK ${ }^{1}$ (D) Emine KARADEMiR ${ }^{2}$ (D) Behzat BARAN $^{1}$ \\ ${ }^{1}$ Plant Protection Research Institute, Diyarbakır, Turkey. \\ ${ }^{2}$ Siirt University, Faculty of Agriculture, Department of Field Crops, Siirt, Turkey.
}

MAKALE BILGISI / ARTICLE INFO

Makale tarihçesi / Article history:

DOI: $10.37908 /$ mkutbd.800392

Geliş tarihi /Received:29.09.2020

Kabul tarihi/Accepted:10.11.2020

\section{Keywords:}

Cotton, wilt, cattle manure, yield, Verticillium dahliae.

Corresponding author: E. KARADEMIR

$\square:$ eminekarademir@siirt.edu.tr

\section{ÖZET / ABSTRACT}

Aims: This study was carried out to determine the effects of different cattle manure treatment $\left(2,4\right.$ and 6 ton $\left.\mathrm{da}^{-1}\right)$ on cotton wilt disease, yield and yield components.

Methods and Results: The experiment was carried out in a farmer's field infected with $V$. dahliae fungus in Diyarbakır. The trials were established according to the split plot design employed in a randomized complete blocks design with three replications. Tolerant GW-Tex and moderately tolerant Stoneville 468 varieties were used as material. Before fertilization soil samples were taken in from the experimental area and the inoculum density of the disease agent was determined. Disease severity values were determined by both foliar symptoms and vascular disease index. In the experimental area, $75 \mathrm{~ms}$ were detected in per gram of soil in 2013. In the second year, except 2 and 4 tonnes da $^{-1}$ cattle manure treatments there was an increase in the density of $\mathrm{ms}$ on the other parcels. The difference between disease severity, treatments, varieties and years was found to be significant according to the average results of two years. The lowest disease index in the stem-section of plant was found as 2 ton $\mathrm{da}^{-1}(1.48)$ in green component evaluation and 4 ton $\mathrm{da}^{-1}(1.58)$ in the vascular system of plant. According to the average results of two years, the disease severity of GW Teks was lower than that of Stv 468. According to cattle manure treatments, seed cotton yield, ginning percentage, plant height, number of sympodial branches and total number of nodes were significantly different, but 100 seed weight, number of monopodial and number of first fruiting branches, boll weight and boll seed cotton weight were non significantly differences. The highest seed cotton yield was obtained with 6 tonnes $\mathrm{da}^{-1}$ cattle manure treatment with $304.61 \mathrm{~kg} \mathrm{da}^{-1}$. The seed cotton yield of GW Teks and Stoneville 468 varieties were $233.15 \mathrm{~kg} \mathrm{da}^{-1}$ and $301.52 \mathrm{~kg} \mathrm{da}^{-1}$, respectively. Conclusions: It has been determined that cattle manure application suppresses Verticillium wilt disease and affects the seed cotton yield positively.

Significance and Impact of the Study: Cattle manure not only increased yield but also made contribution for controlling Verticillium dahliae Kleb. wilt disease. This results, particularly, will be significant for cotton production areas where effected from this diseases.

Atıf / Citation: Sağır P, Bars Orak A, Karademir E, Baran B (2021) Sığır Gübresinin Pamuk Solgunluk Hastalığı (Verticillium dahliae Kleb.) ile Verim ve Verim Parametrelerine Etkisi. MKU. Tar. Bil. Derg. 26(1) : 128-141. DOI: 10.37908/mkutbd.800392 


\section{Giriş}

Pamuk çok çeşitli kullanım alanlarından dolayı, ekonomik ve sosyal açıdan önemli bir kültür bitkisidir. Tekstilden barut ve film malzemesi yapımına kadar yaklaşık 50 kadar sanayi kolunun hammaddesini oluşturan bu kültür bitkisi, ülkemizin en önemli tarımsal ürünlerinden birini oluşturmaktadır (Gencer ve ark., 1998). Ülkemiz, pamuk ekim alanı yönünden Dünyada dokuzuncu (462000 ha), birim alandan elde edilen lif pamuk veriminde üçüncü (1817 kg ha-1), lif pamuk üretim miktarında yedinci (852000 ton), dünya lif pamuk tüketiminde (1481000 ton) ve dünya lif ithalatında dördüncü (792000 ton) sırada yer almaktadır. Türkiye pamuk lif tüketiminin yaklaşık \%40'nı ithalat yoluyla karşılamaktadır. Ülkemizde pamuk, Ege, Çukurova, Antalya ve Güneydoğu Anadolu bölgelerinde yetiştirilmektedir. Türkiye pamuk ekim alanının \%59.4'ü ve üretimin \%56.0'sı Güneydoğu Anadolu bölgesinde gerçekleşmektedir (Anonim, 2018).

Pamuk bitkisinin 20 'den fazla hastalığı bulunmaktadır, fakat en önemlisi $V$. dahliae fungusunun neden olduğu solgunluk hastalığıdır. $V$. dahliae çok yaygın bir konukçu dizisine sahip olup, 400'den fazla bitki türünde hastalığa yol açmaktadır (Schnathorst, 1981; Joaquim ve Rowe, 1990). Tarla bitkileri, çeşitli sebzeler, bazı meyve ağaçları, süs bitkileri ve yabancı otların konukçuları arasında yer aldığı saptanmıştır (Saydam ve Kamal, 1970; Saydam ve ark, 1971; Saydam ve Copçu, 1972; Esentepe ve ark., 1972; Saydam ve ark., 1973; Kocatürk ve Karcilığlu, 1979; Joaquim ve Rowe 1990; Derviş ve ark., 2008). Pamuk solgunluk hastalığı etmeni olan Verticillium dahliae Kleb. bir toprak patojeni olup, kışı toprak ve bitki artıkları üzerinde mikrosklerot halinde geçirebilmekte ve 13-15 yıl kadar uzun bir süre canlılığını sürdürebilmektedir (Schnathorst, 1981; Agrios, 1997). Fungus, bitkiyi özellikle kök ucundan veya hipokotil kısmından enfekte ederek ksilem iletim demetlerini tıkamaktadır. Bitkinin iletim demetlerinin tıkanması sonucunda bir siyahlaşma ve kahverengileşme, yapraklarda ise solma ve pörsüme şeklinde belirtiler ortaya çıkmaktadır. Hastalığın kütlü pamuk ve lif verimini olumsuz yönde etkilediği ayrıca lif kalitesini azalttığı belirtilmektedir.

Verticillium ülkemizde ilk kez 1941 yılında Manisa Kırkağaç'ta saptanmıştır (İyriboz, 1941), ancak etmeninin Verticillium dahliae olduğu daha sonra yürütülen bir çalışmada belirlenmiştir (Karaca ve ark., 1971). Ülkemizde yürütülen farklı çalışmalarda, pamukta solgunluk hastalığına yakalanma oranın, Batı Akdeniz'de (Antalya) \% 14, Güneydoğu Anadolu Bölgesinde \% 16, Çukurova'da (Adana) \% 25 ve Ege Bölgesinde \% 27 olduğu, ürün kaybının ise Ege Bölgesinde \% 12, Adana'da $\%$ 12, Antalya'da \% 4 olduğu bildirilmiştir (Esentepe, 1979; Sezgin, 1985; Sağır ve ark., 1995). Yapılan çeşitli çalışmalarda kütlü pamuk verimi, 100 tohum ağırlığı, tohumun çimlenme oranı ile solgunluk hastalığının şiddeti arasında olumsuz bir korelasyonun bulunduğu hastalığın çırçır randımanını etkilediği bildirilmiştir (Kaymak ve ark., 1976; El-Zik, 1985; Yelin ve Erşan, 1985; Sağır ve Aydın, 2001; Sağır ve Başbağ, 2002; Erdoğan ve ark., 2006; Erdoğan ve Benlioğlu, 2007; Erdoğan ve Dündar, 2007; Karademir ve ark., 2012).

Diyarbakır koşullarında, 26 pamuk çeşidi ile yürütülen çalışmada, çeşitlerin 0-3 skalasına göre hastalık şiddetinin 0.25 ile 1.40 ve verimin ise 257.8 ile $405.9 \mathrm{~kg}$ $\mathrm{da}^{-1}$ arasında değiştiği saptanmıştır (Sağır ve Aydın, 2001). Aynı ekolojik koşullarda yapılan başka çalışmada, GW Teks ve Stoneville 468 pamuk çeşitlerinin verim bakımından aynı grupta yer aldıkları bildirilmiştir (Karademir ve ark., 2015; Karademir ve ark., 2017).

$V$. dahliae fungusu bir toprak patojeni olup, etmene karşı ekonomik, etkili ve başarılı bir kimyasal mücadele yöntemi uygulanamamakta, hastalığın kontrolü için daha çok kültürel önlemler üzerinde durulmaktadır. Kültürel önlemlerin başında, hastalığa karşı dayanıklı ya da tolerant çeşitlerin yetiştirilmesi, ekim nöbeti, ekim zamanı ve ekim sıklığı, dengeli gübreleme, sulama suyunun miktarı, sulama zamanı ve sulama yöntemi, yabancı ot ile mücadele gelmektedir (El-Zik 1985; Godoy ve ark., 1995; Kurt ve Biçici, 1998; Anonim, 2000; Anonim, 2008; Erdemci ve Sağır, 2001; Erdemci ve ark., 2003). Hastalığın kontrolünde yeni kültürel önlemlerin yöntem ve yaklaşımların geliştirilmesi önemlidir.

Ülkemizde sığır gübresinin ve organik maddenin pamuk solgunluk hastalığı ile verim ve verim parametrelerine olan etkisi konusunda çok az araştırma yapılmıştır. Gübreleme konusunda yürütülen araştırmalarda, potasyum eksikliğinin veya azotlu gübrelemenin yüksek miktarlarının Verticillium solgunluğunun çıkış ve şiddetini artırdığı (Nemli, 2003), tavuk ve sığır gübresinin kullanılması ile pamukta toprak kaynaklı hastalıklara karşı toleransın arttırılabileceği, böylece hastalığın şiddetinde ve oranında azalma olduğu bildirilmiştir (Fard ve ark., 2005). Kaba yoncanın kök ekstraktlarının pamukta $V$. dahliae'nin mikrosklerot oluşturmasını bastırdığı saptanmıştır (Bora, 1975). Verticillium solgunluk hastalığına karşı Çukurova bölgesinde yürütülen çalışmada, yeşil gübre olarak kullanılan bakla, fiğ ve kolzanın hastalık çıkışını olumsuz yönde etkilediği, bu gübrelerin hastalığın şiddetini sırasıyla \% 14.04, \% 38.60 ve \% 47.37 oranında düşürdüğü bildirilmiştir (Derviş ve Biçici, 2005). Ege bölgesinde yürütülen bir çalışmada arpa, fiğ ve arpa + fiğ karışımı yeşil gübre 
olarak kullanılmıştır. Arpa ve arpa + fiğ yeşil gübre uygulamalarının hastalık şiddeti üzerinde kontrol üretim parselinden daha yüksek bir azalmaya sebep olduğu, ortalama verim değerlerinin fiğ ve kontrol parsellerinde arpa + fiğ ve arpa üretim parsellerine göre daha yüksek olduğu tespit edilmiştir (Erdoğan ve ark., 2012). Kerkeni ve ark. (2007) birkaç kompost ekstraktına hayvan gübresi karışımı ilave ederek in vitro koşullarda antifungal aktiviteleri Verticillium dahliae'ye karşı en yüksek engelleme oranının \% 76.2 ile C9 (\%25 sığır gübresi + \%25 koyun gübresi $+\% 25$ kümes hayvanları gübresi $+\% 25$ at gübresi) ekstraktı ile elde edildiğini bildirmişlerdir.

Bu çalışma, pamukta Verticillium solgunluk hastalığına karşı yeni mücadelede önlemler geliştirmek, sığır gübresinin farklı miktarlarının pamuk solgunluk hastalığı şiddeti ile pamuk verimi ve verim parametrelerine etkilerini belirlemek amacıyla yürütülmüştür.

\section{MATERYAL ve YÖNTEM}

\section{Verticillium dahliae'nin mikrosklerot yoğunluğunun belirlenmesi}

Verticillium dahliae'nin mikrosklerot yoğunluğunu belirlemek amacıyla pamuk ekiminden önce her iki yılda Nisan ayında deneme alanından $0-20 \mathrm{~cm}$ derinlikten toprak örnekleri alınmış, alınan örnekler bir ay süreyle naylon örtü üzerine $1-2 \mathrm{~cm}$ kalınlığında serilmiş, bu sürenin 1. haftasının sonunda toprak iyice ezilerek ufaltılmıştır. Geriye kalan 3 haftalık süre içinde toprak yine ince bir şekilde serilerek bekletilmiştir. Toprak örneği, önce $2 \mathrm{~mm}$ genişliğindeki elekten sonra 38 mikronluk elekten geçirilmiştir. Elenmiş bu topraktan $250 \mathrm{~g}$ alınarak çalışmalarda kullanılmak üzere ayrılmıştır. Mikrosklerot yoğunluklarının belirlenmesi, Kabir ve ark. (2004)'nın önerdiği yönteme göre gerçekleştirilmiştir.

\section{Tarla Denemelerinin Kurulması}

Her iki yıldaki denemeler, Mayıs ayının son haftasında Diyarbakır'ın Bismil îlçesinde daha önce solgunluk hastalığının yoğun olarak görüldüğü, $V$. dahliae ile doğal olarak bulaşık bir üretici tarlasında kurulmuştur. Denemeler tesadüf bloklarında bölünmüş parseller deneme desenine göre 3 tekrarlamalı olarak yürütülmüştür. Ana parselleri çeşit, alt parselleri ise gübre uygulamaları oluşturmuştur. Sıra arası mesafe 70 $\mathrm{cm}$ olacak şekilde her parsel $10 \mathrm{~m}$ uzunluğunda 8 sıradan oluşturulmuştur. Sıra üzeri mesafe ise $15-20 \mathrm{~cm}$ olacak şekilde seyreltme yapılmıştır. Parsel alanı $0.7 \mathrm{~m} \times 8$ sıra $\mathrm{x}$ $10 \mathrm{~m}=56 \mathrm{~m}^{2}$ dir. Uygulamaların parselleri etkilemelerini önlemek amacıyla parseller arasında $2 \mathrm{~m}$ boşluk bırakılmıştır. Denemelerde 5 farklı uygulama $(2,4$ ve 6 ton $\mathrm{da}^{-1}$ sığır gübresi, kontrol ve çiftçi uygulaması) yer almıştır. Çalışmalarda, solgunluk hastalığına kaşı tolerant GW Teks ile orta derecede tolerant olduğu bilinen Stoneville 468 pamuk çeşitleri bitki materyali olarak kullanılmıştır (Karademir ve ark., 2012; Harem, 2014). Çiftçi uygulaması olarak ticari gübre 20:20:0 kompoze gübre formunda $40 \mathrm{~kg} \mathrm{da}^{-1}$ olarak uygulanmış, kontrol parsellerine ise herhangi bir gübre verilmemiştir. Yanmış çiftlik gübresi, 01.05.2013 tarihinde 2, 4 ve 6 ton da ${ }^{-1}$ olacak şekilde parsellere dağıtılmış ve daha sonra kültivatörle toprağa karıştırılmıştır. Toprak iki kez düzleştirildikten sonra ekim mibzer ile gerçekleştirilmiştir. 2014 yılında da aynı parsellere GW Teks ve Stoneville 468 pamuk çeşitleri ekilmiş, fakat sığır gübresi uygulamadan deneme tekrar kurulmuştur. Pamuk yetiştirme sezonu boyunca 7 kez karık usulü sulama yapılmış, seyreltme, çapalama ve yabancı ot kontrolü gibi kültürel uygulamalar zamanında ve usulüne uygun bir şekilde gerektiği dönemlerde yapılmıştır.

\section{Hastalık Değerlendirmesi}

Hastalık değerlendirilmesi yeşil aksam ve gövde kesitine (iletim demetindeki renk değişikliğine) göre yapılmıştır. Yeşil aksamda yaprak belirtileri, kozaların \% 5-10 ve \% 50-60 açtığı dönemde, her parselin ortasındaki 2 sırada yer alan bitkilerden tesadüfen 40 adet seçilerek 0-4 skalasına göre değerlendirilmiştir (Bejarano-Alcazar ve ark., 1995). Gövde kesitine göre solgunluk hastalığı şiddeti, pamuk hasadından sonra her parselin ortasındaki 2 sıradaki tüm bitkilerin gövdeleri toprak seviyesinden 5-6 cm yukarıdan kesilerek iletim demetlerinin renk değişikliğine göre $0-3$ skalası kullanılarak değerlendirilmiştir (Erwin ve ark., 1976).

\section{Verim ve Verim Parametreleri}

Deneme parsellerinin ortasındaki iki sırada 1 . ve 2. el pamuk hasadı yapılmıştır. Birinci el pamuk hasadı kozaların \%60'ının açtığı dönemde, ikinci el hasat ise 1. el hasadından yaklaşık olarak 20 gün sonra elle yapılarak hasat işlemi tamamlanmıştır. Çeşitlerin verimleri dekara göre hesaplanmış, tesadüfen seçilen 10 bitkide verim unsurları olan bitki boyu, odun dalı sayısı, meyve dalı sayısı, ilk meyve dalı boğum sayısı, koza sayısı, koza ağırlığı, koza kütlü ağırlığı, toplam boğum sayısı, çırçır randımanı ve 100 tohum ağırlığı değerleri incelenmiştir. Koza değerlendirmeleri için parsellerin ortasındaki iki sıradan tesadüfen alınan 40 adet koza değerlendirilmiştir. 
Çizelge 1. Pamuk bitkisinin yeşil aksam 0-4 solgunluk skalası (Bejarano-Alcazar ve ark., 1995)

Table 1. Foliar symptom severity of cotton plant ( 0-4 scale ) (Bejarano et al., 1995)

\begin{tabular}{ll}
\hline Skala değeri & Hastalık belirtileri \\
\hline $\mathbf{0}$ & Bitkiler sağ $/ ı k$ ı \\
$\mathbf{1}$ & Bitkilerin \% 1-33'ünde hastalık belirtisi \\
$\mathbf{2}$ & Bitkilerin \% 34-66'sında hastalık belirtisi \\
$\mathbf{3}$ & Bitkilerin \% 67-97'sinde hastalık belirtisi \\
$\mathbf{4}$ & Bitkiler tamamen ölmüş \\
\hline
\end{tabular}

Çizelge 2. Pamuk bitkisinin iletim demeti renklenmesine göre 0-3 solgunluk skalası (Erwin ve ark., 1976)

Table 2. Vascular disease severity (0-3 wilt scale) according to vascular discoloration of cotton plant (Erwin et al., 1976)

\begin{tabular}{ll}
\hline Skala değeri & Hastalık belirtileri \\
\hline $\mathbf{0}$ & Bitki sağlıklı \\
$\mathbf{1}$ & Bitki iletim demetlerinin \%1-33'ü kahverengileşmiş \\
$\mathbf{2}$ & Bitki iletim demetlerinin \%34-67'sı kahverengileşmiş \\
$\mathbf{3}$ & Bitki iletim demetlerinin \%68-100'ü kahverengileşmiş \\
\hline
\end{tabular}

\section{Sonuçların Değerlendirilmesi}

Denemelerde elde edilen özelliklere ait verilerin varyans analizleri JUMP 5.0.1 istatistik paket program yardımı ile değerlendirilmiş, (Yurtsever, 1984); ortalamaların karşılaştırılmasında ise $\operatorname{LSD}_{(0.05)}$ testi kullanılmıştır.

\section{BULGULAR ve TARTIŞMA}

\section{Deneme Alanında Verticillium dahliae'nin mikrosklerot yoğunluğunun belirlenmesi}

2013 yılında deneme alanından alınan toprak örneklerinde yapılan analizlerde bir gram kuru toprakta ortalama 75 adet mikrosklerot (ms) tespit edilmiştir. Denemenin ikinci yılında ise farklı karakterleri temsil eden ayrı parsellerden alınan toprak örneklerinin gram başına propagül sayısının; kontrolde $77 \mathrm{~ms} \mathrm{~g}^{-1}$, çiftçi uygulamasında $85 \mathrm{~ms} \mathrm{~g}^{-1} ; 2,4$ ve 6 ton $\mathrm{da}^{-1}$ sığır gübresi uygulamalarında sırasıyla 74,72 ve $79 \mathrm{~ms} \mathrm{~g}^{-1}$ olduğu saptanmıştır. Her iki yılda da deneme alanında yeterli düzeyde hastalığın ortaya çıktığı görülmüştür. Pamuk solgunluğu ile ilgili Kaliforniya'da yapılan bir çalışmada, toprakta inokulum yoğunluğu $5-60 \mathrm{~ms} \mathrm{~g}^{-1}$ olduğunda hastalıklı bitki oranının \% 15 ile 95 arasında değiştiği belirtilmektedir (El-Zik, 1985). Çukurova bölgesinde bir gram toprakta 10 adet mikrosklerot olduğunda yeterli düzeyde hastalığın ortaya çıktığı saptanmıştır (Derviş ve Biçici, 2005).

\section{Hastalık Değerlendirmeleri}

Farklı sığır gübresi miktarlarının pamuk solgunluk hastalığı (V. dahliae)'na etkilerini belirlemek için yapılan çalışmalarda yıllara ve deneme konularına göre yeşil aksam ve gövde kesiti hastalık değerlendirilmesinde elde edilen sonuçlar Çizelge 3'te verilmiştir.
Kozaların \% 5-10 açma döneminde yapılan hastalık değerlendirmelerinde uygulamalara, çeşitlere ve yıllara göre hastalık indeksinin \%1 düzeyinde önemli olduğu görülmektedir (Çizelge 3). En düşük hastalık indeksi 2 ton $\mathrm{da}^{-1}$ (1.48) gübre uygulamasından elde edilirken, en yüksek hastalık indeksi değeri ise çiftçi uygulamasından (1.77) elde edilmiştir. Denemenin ilk yılında (2013 yılında) \% 5-10 yeşil aksam hastalık indeksi değerinin 1.38, denemenin ikinci yılında (2014 yılı) ise hastalık indeksi değerinin 1.84 olduğu tespit edilmiştir. \%5-10 koza açma döneminde yeşil aksam hastalık indeksi yönünden çeşit farklılı̆ıının da önemli olduğu Çizelge 3'te görülmektedir. Yapılan iki yıllık birleşik varyans analiz sonucuna göre GW Teks çeşidinin daha düşük hastalık şiddeti değerine sahip olduğu tespit edilmiştir. GW Teks çeşidinde hastalık indeksi değerinin 1.38 olduğu Stoneville 468 çeşidinin ise 1.85 olduğu belirlenmiştir. Yıl $x$ uygulama $x$ çeşit interaksiyonu \%1 düzeyinde önemli olup, en düşük hastalık şiddeti değeri 2013 yılında GW Teks çeşidinin kontrol uygulamasından (1.04) elde edilirken, en yüksek değerin ise 2014 yılında Stoneville 468 çeşidinden ve çiftçi uygulamasından (2.22) elde edildiği belirlenmiştir.

Kozaların \%50-60 açtığı dönemde alınan yeşil aksam hastalık indeksi değerleri Çizelge 3'te görülmektedir. Çizelge 3'ten izlenebileceği gibi bu dönemdeki yeşil aksam hastalık indeksi yönünden yıl, yıl $x$ uygulama ve çeşit \% 1 düzeyinde önemli, yıl $x$ uygulama $x$ çeşit interaksiyonu \% 5 düzeyinde önemli bulunmuştur. İki yılın birleşik analiz değerlerine göre uygulamalara bağlı olarak hastalık indeksi değerleri önemsiz bulunmuştur. Ancak en düşük hastalık indeksi 2 ton da $^{-1}(1.78)$, en yüksek ise 6 ton da ${ }^{-1}$ (2.01) sığır gübresi uygulamasında saptanmıştır. Yıllara göre hastalık şiddeti değerleri farklı 
bulunmuş ve ayrı gruplarda yer almıştır. Hastalık şiddeti değerinin 2013 yılında 1.75, 2014 yılında ise 2.01 olduğu saptanmıştır. İki yıllık ortalamaya göre \%50-60 yeşil aksam hastalık indeksi yönünden çeşit farklıı̆ı̆ının önemli olduğu belirlenmiş ve farklı gruplarda yer almıştır. GW Teks çeşidinin ortalama hastalık şiddeti değerinin 1.66, Stoneville 468 çeşidinin ise 2.11 olduğu belirlenmiştir. Yıl x uygulama interaksiyonu önemli olup, en düşük hastalık şiddeti değeri (1.57) 2013 yılında kontrol uygulamadan elde edilirken, en yüksek değer (2.23) 2014 yılında yine kontrol uygulamadan elde edilmiştir.

Çizelge 3. Yeşil aksam ve gövde kesitine göre solgunluk hastalığı şiddeti değerleri

Table 3. Foliar and vascular disease severity values of Verticillium wilt

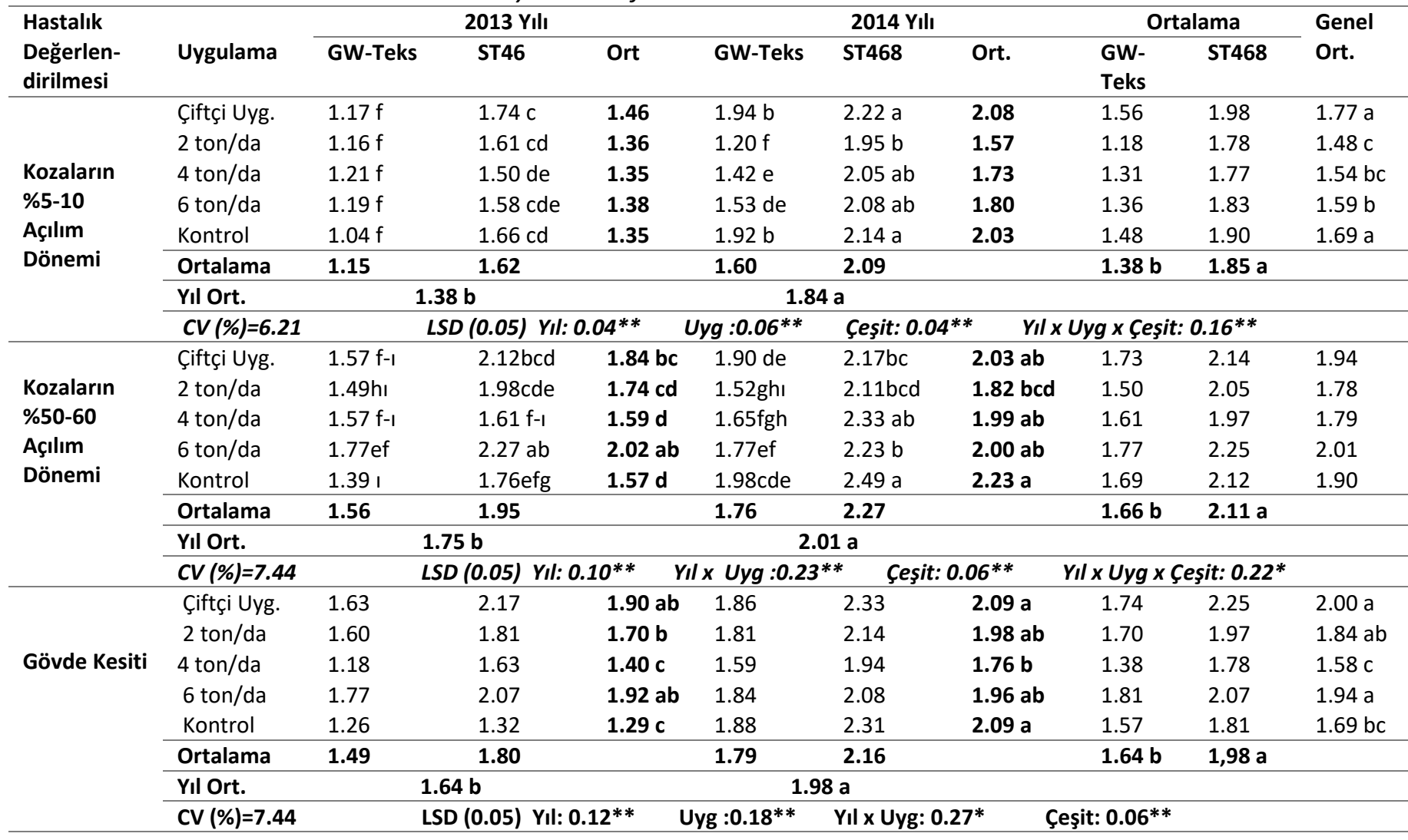

Gövde kesiti hastalık indeksi değerleri bakımından yıl, uygulama ve çeşit \% 1 düzeyinde önemli, yıl x uygulama interaksiyonu ise $\% 5$ düzeyinde önemli bulunmuştur (Çizelge 3).

Çizelgede 3'te görüldüğü üzere uygulamalar farklı gruplarda yer almıştır. En düşük hastalık indeksi değeri (1.58) ile 4 ton da $^{-1}$ sığır gübresinden, en yüksek hastalık indeksi değeri (2.00) ise çiftçi uygulamasından elde edilmiştir. Gövde kesiti hastalık indeksi bakımından yıl ve çeşit farklılığının önemli olduğu belirlenmiş, hem yıl hem çeşide göre 2013 yılında hastalık indeksi değerinin 1.64, 2014 yılında ise 1.98 olduğu tespit edilmiştir. Yıl x uygulama interaksiyonu incelendiğinde en düşük hastalık indeksi değerinin 2013 yılında kontrol uygulamasından (1.29) elde edildiği, en yüksek değerin ise 2014 yılında çiftçi (2.09) ve kontrol (2.09) uygulamalarından elde edildiği görülmektedir (Çizelge 3).
Farklı sığır gübresi uygulamalarında kozaların \%5-10’nün açtığı dönemde yeşil aksam ile gövde kesitine göre yapılan hastalık değerlendirmesi farklı bulunmuştur. Kozaların \%5-10 açtığı dönemde en düşük hastalık şiddeti 2 ton da-1 sığır gübresi (1.48) uygulamasından, gövde kesitinde ise 4 ton $\mathrm{da}^{-1}$ (1.58) uygulamasından elde edilmiştir. En yüksek hastalık şiddeti değerleri ise her iki değerlendirmede de çiftçi uygulamasından elde edilmiştir. Kozaların \%50-60 açtığı dönemde gübre uygulamalarına göre hastalık şiddeti değerleri farksız bulunmuştur. Ancak en düşük hastalık şiddeti 2 ton da ${ }^{-1}$ sığır gübresi uygulamasından elde edilmiştir. Her üç değerlendirmede de yıllara göre hastalık şiddeti değerleri farklı gruplarda yer almıştır. Hastalık şiddeti 2013 yılına göre 2014 yılında daha yüksek bulunmuştur. Aynı şekilde gram topraktaki mikrosklerot sayısında da bir artış olmuştur. Yani topraktaki inokulum artışıyla hastalık şiddetinin artışı arasında bir paralellik mevcuttur. Pamuk solgunluk hastalığının etmeni $V$. 
dahliae fungusu bir toprak patojeni olup, hastalığın çıkışı ve şiddeti üzerine birçok faktör etkili olmaktadır. Bu faktörlerin başında çevre koşulları, topraktaki inokulum miktarı, yetiştirilen pamuk çeşidinin duyarlılık düzeyi, ekim nöbeti, kullanılan gübrenin cinsi ve formu, sulama suyu miktarı ve sulama yöntemi, ekim zamanı ve ekim sıklığı gibi etkenler gelmektedir (El-Zik, 1985; Karcılıoğlu ve ark., 1985; Godoy ve ark., 1995; Kurt ve Biçici, 1998; Sağır ve Başbağ, 1998; Yıldırım ve Sağır, 1999; Anonim, 2000; Erdemci ve Sağır, 2001; Erdemci ve ark., 2003).

Yapılan farklı çalışmalarda toprağa organik maddenin ilave edilmesiyle pamukta solgunluk hastalığı çıkışının azaldığı bildirilmiştir. Nitekim kaba yoncanın kök ekstraktlarının pamukta $V$. dahliae'nin mikrosklerot oluşturmasını bastırdığını (Bora, 1975), in vitro koşullarda aynı patojene karşı en yüksek engelleme oranı $\% 76.2$ ile $\% 25$ sığır gübresi $+\% 25$ koyun gübresi $+\% 25$ kümes hayvanları gübresi $+\% 25$ at gübresi ekstraktı ile elde edildiği saptanmıştır (Kerkeni ve ark., 2007). Hasat edilen şerbetçi otu yaprak ve sapları, mineral ve organik gübrelerle birlikte çeşitli bitkilerin rizosferine uygulandığında, sadece mineral gübrelerin uygulandığı bitkilerde Verticillium solgunluğunun \%17 arttığı, sadece organik gübrelerin uygulandığı bitkilerde ise Verticillium solgunluğunun \% 14 oranında azaldığı bildirilmiştir (Rossbauer ve Zwack, 1982).

Denemelerde kullanılan GW Teks ve Stoneville 468 çeşitleri hem yeşil aksam hem de gövde kesiti hastalık şiddeti değerlendirmesinde farklı gruplarda yer almıştır. Her üç değerlendirmede de GW Teks çeşidinin hastalık şiddeti Stoneville 468'e göre daha düşük bulunmuştur. Bu çalışmada elde edilen sonuçlar daha önce bu konuda yapılan çalışmalarla benzerlik göstermektedir. Nitekim GW Teks çeşidinin solgunluk hastalığına karşı tolerant, Stoneville 468 çeşidinin ise orta derece tolerant olduğu belirtilmiştir (Karademir ve ark., 2012; Harem, 2014).

\section{Kütlü Pamuk Verimi, Çırçır Randımanı ve 100 Tohum Ağırlı̆̆ı}

Gübre uygulamaları, yıllara ve çeşitlere göre elde edilen pamuk verim değerleri Çizelge 4 'de verilmiştir. Pamuk verimi uygulamalara ve çeşitlere göre $\% 1$ düzeyinde önemli istatistiki farklııık göstermiş ve farklı gruplarda yer almıştır. Uygulamalar incelendiğinde iki yılın ortalamasına göre en yüksek kütlü pamuk veriminin 6 ton $\mathrm{da}^{-1}$ gübre uygulamasından $\left(304.61 \mathrm{~kg} \mathrm{da}^{-1}\right)$, en düşük verimin ise çiftçi uygulamasından (233.98 $\mathrm{kg} \mathrm{da}^{-1}$ ) ve kontrol parselinden (242.45 $\left.\mathrm{kg} \mathrm{da}^{-1}\right)$ elde edildiği görülmektedir. Çiftçi uygulaması ile karşılaştırıldığında 6 ton $\mathrm{da}^{-1}$ gübre uygulamasının $70 \mathrm{~kg} \mathrm{da}^{-1}$ verim artışına yol açtığı anlaşılmaktadır. Çeşit farklıığı önemli bulunmuş olup, Stoneville 468 çeşidi (301.52 kg da-1) kütlü pamuk verimi ile GW Teks (233.15 $\mathrm{kg} \mathrm{da}^{-1}$ ) çeşidinden daha yüksek verim değerini göstermiştir.

Yapılan bu çalışmanın sonucunda farklı sığır gübresi dozu uygulamasının kütlü pamuk verimi üzerine etkili olduğu en yüksek verimin 6 ton da ${ }^{-1}$ uygulamasında $(304.61 \mathrm{~kg}$ $\mathrm{da}^{-1}$ ) elde edildiği saptanmıştır. Toprağa organik materyalin ilave edilmesiyle pamuğun veriminde artış sağlanabileceği daha önce yapılan farklı çalışmalarda da benzer sonuçlar elde edilmiştir. Hayvan gübresi ve yeşil gübrenin toprak özellikleri ve ürün verimliliği (pamuk, mısır, buğday) üzerine etkilerinin araştırıldığı bir çalışmada özellikle hayvan gübresi kullanılan alanlarda verimde önemli bir artış olduğu, ayrıca hayvan gübresi ve yeşil gübrenin topraktaki azot ve fosfor oranına katkı sağladığı bildirilmiştir (Gaerli ve ark., 2015). Ülkemizde değişik araştırıcılar tarafından yapılan çalışmalarda adi fiğ, bakla, yem bezelyesi, arpa, yemlik kolza ve adi fiğ + arpa karışımı yeşil gübre olarak kullanılmıştır. En yüksek verimin fiğ uygulamasından elde edildiği, bakla ve yem bezelyesi yeşil gübrelemesi ile ticari azotlu gübre uygulamasının da kütlü pamuk verimini olumlu yönde artırdığı saptanmıştır (Aygün, 1992; Derviş ve Biçici, 2005; Erdoğan ve ark., 2012).

Güneydoğu Anadolu bölgesinde değişik pamuk çeşitleri kullanılarak yapılan çalışmalarda farklı kütlü pamuk verimleri elde edilmiştir. Bilindiği gibi kütlü pamuk verimi üzerine toprak koşulları, kullanılan gübrenin cinsi ve miktarı, sulama yöntemi ve tüketilen su miktarı gibi faktörler etkili olmaktadır. Diyarbakır ekolojik koşullarında farklı azot ve fosfor dozlarının kütlü pamuk verimi üzerine, azot dozları ve $\mathrm{N} \times \mathrm{P}$ interaksiyonun önemli olduğu ve en ekonomik uygulamanın $12 \mathrm{~kg} \mathrm{~N} / \mathrm{da}$ $+8 \mathrm{~kg} \mathrm{P}_{2} \mathrm{O}_{5} /$ da kombinasyonu olduğu (Karademir ve ark., 2005), aynı ekolojik koşullarda yapılan başka çalışmalarda GW Teks ve Stoneville 468 pamuk çeşitlerinin kütlü verimi bakımından aynı grupta yer aldıkları bildirilmiştir (Karademir ve ark., 2015; Karademir ve ark., 2017). Bismil koşullarında 26 pamuk çeşidi ile yürütülen bir çalışmada, çeşitlerin hastalık oranının \% 23.5 ile \% 58.9, 0-3 skalasına göre hastalık şiddetinin 0.25 ile 1.40 , verimin ise $257.8 \mathrm{~kg} \mathrm{da}^{-1}$ ile 405.9 $\mathrm{kg} \mathrm{da}^{-1}$ arasında değiştiği saptanmıştır (Sağır ve Aydın, 2001). Harran Ovası koşullarında 10 pamuk çeşidinin fenolojik özellikleri konusunda yapılan çalışmada, kütlü pamuk veriminin $318 \mathrm{~kg} \mathrm{da}^{-1}$ ile $487 \mathrm{~kg} \mathrm{da}^{-1}$ arasında değiştiği, en yüksek kütlü pamuk veriminin Stoneville 453 pamuk çeşidinden alındığı, GW Teks çeşidinin kütlü pamuk verimi değerinin 2006 yılında $338.54 \mathrm{~kg} \mathrm{da}^{-1}, 2007$ yılında ise $323.15 \mathrm{~kg} \mathrm{da}^{-1}$ olduğu bildirilmiştir (Çopur ve Birgül, 2017).

Çırçır randımanı yönünden gübre uygulamaları arasında \% 5 düzeyinde önemli istatistiki farklılıkların olduğu ve 
uygulamaların farklı gruplarda yer aldığı belirlenmiştir (Çizelge 4). En yüksek çırçır randımanı değeri kontrol uygulamadan (\% 48.31), en düşük çırçır randımanı değeri ise 2 ton da ${ }^{-1}$ uygulamasından (\% 46.34) elde edilmiştir. Çırçır randımanı özelliğinde yıllar ve çeşitler arasında önemli bir istatistiki farklılık görülmemiştir. Çırçır randımanı konusunda daha önce yürütülen araştırmalarda farklı sonuçlar elde edilmiştir. Diyarbakır ekolojik koşullarında farklı azot ve fosfor dozlarının pamuğun çırçır randımanı üzerine önemli bir etkisinin olmadığı (Karademir ve ark., 2005), öte yandan Carmen, Deltapine 90, Maraş 92 ve SG 125 pamuk çeşitleriyle Diyarbakır'da üretici tarlasında yapılan çalışmada, çırçır randımanın hastalıklı bitkilerde sağlıklı bitkilere göre daha yüksek bulunduğu saptanmıştır (Sağır ve Başbağ, 2002). Blaise ve ark. (2005), çiftlik gübresinin çırçır randımanını olumlu yönde etkilediğini bildiren araştırma bulguları ile farklı sonuçların elde edildiği görülmektedir. 100 tohum ağırlığı yönünden çeşit farklılığının \%1 düzeyinde, yıl farklılığının ise $\% 5$ düzeyinde önemli olduğu belirlenmiştir (Çizelge 4). Çeşitler 100 tohum ağırlığı yönünden farklı gruplarda yer almıştır. GW Teks çeşidi $11.74 \mathrm{~g}$ değeri ile a grubunda yer alırken Stoneville 468 çeşidi $9.76 \mathrm{~g}$ değeri ile $b$ grubunda yer almıştır. Yıl farklılı̆ının önemli olduğu, 2013 yılında 100 tohum ağırlığı değerinin $10.43 \mathrm{~g}, 2014$ yılında ise $11.08 \mathrm{~g}$ olduğu, 100 tohum ağırlığının 2014 yılında daha fazla olduğu saptanmıştır.

Gübre uygulamalarına göre 100 tohum ağırlığı istatistiksel olarak farksız bulunmuştur. Bu konuda değişik çalışmalar yapılmıştır. Nitekim Carmen, Deltapine 90, Maraş 92 ve SG 125 pamuk çeşitleri kullanılarak yapılan bir çalışmada, sağlıklı bitkilerin 100 tohum ağırlığının hasta bitki tohumlarına göre daha fazla olduğu (Sağır ve Başbağ, 2002), keza yapılan başka bir çalışmada hastalık şiddeti ile 100 tohum ağırlığı arasında negatif bir ilişkinin olduğu, hastalık şiddetinin artması ile tohum ağırlığının azaldığı bildirilmiştir (Sakçı, 2015).

Çizelge 4. Kütlü pamuk verimi, çırçır randımanı ve 100 tohum ağırlığı değerleri

Table 4. The values of seed cotton yield, ginning percentage and 100 seed weight

\begin{tabular}{|c|c|c|c|c|c|c|c|c|c|c|}
\hline \multirow{2}{*}{$\begin{array}{l}\text { Verim ve } \\
\text { Verim } \\
\text { Unsurları }\end{array}$} & \multirow[b]{2}{*}{ Uygulama } & \multicolumn{3}{|c|}{2013 Yilı } & \multicolumn{3}{|c|}{2014 Yılı } & \multicolumn{2}{|c|}{ Ortalama } & \multirow[t]{2}{*}{ Genel Ort. } \\
\hline & & $\begin{array}{l}\text { GW- } \\
\text { Teks }\end{array}$ & ST468 & Ort. & $\begin{array}{l}\text { GW- } \\
\text { Teks }\end{array}$ & ST468 & Ort. & GW-Teks & ST468 & \\
\hline \multirow{8}{*}{$\begin{array}{l}\text { Verim } \\
\left(\mathrm{kg} \mathrm{da}^{-1}\right)\end{array}$} & Çiftçi & 196.66 & 305.00 & 250.83 & 217.85 & 216.42 & 217.14 & 207.26 & 260.71 & $233.98 c$ \\
\hline & 2 ton/da & 187.32 & 287.26 & 237.29 & 245.47 & 335.47 & 290.47 & 216.39 & 311.36 & $263.88 \mathrm{bc}$ \\
\hline & 4 ton/da & 289.70 & 309.40 & 299.55 & 230.59 & 337.38 & 283.98 & 260.14 & 323.39 & $291.77 a b$ \\
\hline & 6 ton/da & 279.94 & 316.25 & 298.09 & 268.21 & 354.04 & 311.13 & 274.07 & 335.14 & $304.61 \mathrm{a}$ \\
\hline & Kontrol & 230.05 & 261.90 & 245.98 & 185.71 & 292.14 & 238.92 & 207.88 & 277.02 & $242.45 \mathrm{c}$ \\
\hline & Ortalama & 236.73 & 295.96 & & 229.57 & 307.09 & & $233.15 \mathrm{~b}$ & 301.52 a & \\
\hline & Yıl Ort. & \multicolumn{2}{|c|}{266.35} & & \multicolumn{2}{|c|}{268.33} & & & & \\
\hline & \multicolumn{2}{|l|}{$C V(\%)=17.07$} & \multicolumn{3}{|c|}{ LSD (0.05) Uyg: $34.77^{* *}$} & \multicolumn{2}{|c|}{ Çeşit: $24.52 * *$} & & & \\
\hline \multirow{8}{*}{$\begin{array}{l}\text { Çırçır } \\
\text { Randımanı } \\
\text { (\%) }\end{array}$} & Çiftçi & 46.20 & 47.36 & 46.78 & 45.48 & 47.22 & 46.35 & 45.84 & 47.29 & $46.56 \mathrm{c}$ \\
\hline & 2 ton/da & 46.31 & 47.65 & 46.98 & 45.02 & 46.36 & 45.69 & 45.67 & 47.01 & $46.34 \mathrm{c}$ \\
\hline & 4 ton/da & 46.79 & 48.27 & 47.53 & 47.24 & 49.25 & 48.25 & 47.01 & 48.76 & $47.89 \mathrm{ab}$ \\
\hline & 6 ton/da & 49.17 & 44.25 & 46.71 & 44.82 & 48.39 & 46.61 & 47.00 & 46.32 & $46.66 \mathrm{bc}$ \\
\hline & Kontrol & 47.21 & 49.98 & 48.70 & 47.47 & 48.37 & 47.92 & 47.44 & 49.17 & $48.31 \mathrm{a}$ \\
\hline & Ortalama & 47.18 & 47.50 & & 46.01 & 47.92 & & 46.59 & 47.71 & \\
\hline & Yıl Ort. & \multicolumn{2}{|c|}{47.34} & & \multicolumn{2}{|c|}{46.96} & & & & \\
\hline & \multicolumn{2}{|l|}{$C V(\%)=5.49$} & \multicolumn{5}{|c|}{ LSD (0.05) Uyg: $1.24^{*}$} & & & \\
\hline \multirow{8}{*}{$\begin{array}{c}100 \\
\text { Tohum } \\
\text { Ağırlığı (g) }\end{array}$} & Çiftçi & 11.96 & 9.43 & 10.70 & 12.03 & 10.60 & 11.31 & 12.00 & 10.01 & 11.00 \\
\hline & 2 ton/da & 11.46 & 9.76 & 10.61 & 12.80 & 10.76 & 11.78 & 12.13 & 10.26 & 11.20 \\
\hline & 4 ton/da & 11.70 & 9.26 & 10.48 & 11.46 & 10.16 & 10.81 & 11.58 & 9.71 & 10.65 \\
\hline & 6 ton/da & 11.66 & 9.36 & 10.51 & 11.70 & 10.23 & 10.96 & 11.68 & 9.80 & 10.74 \\
\hline & Kontrol & 11.03 & 8.63 & 9.83 & 11.60 & 9.43 & 10.51 & 11.31 & 9.03 & 10.17 \\
\hline & Ortalama & 11.56 & 9.29 & & 11.92 & 10.24 & & $11.74 \mathrm{a}$ & $9.76 \mathrm{~b}$ & \\
\hline & Yıl Ort. & \multicolumn{2}{|c|}{$10.43 \mathrm{~b}$} & & \multicolumn{2}{|c|}{$11.08 \mathrm{a}$} & & & & \\
\hline & $C V(\%)=5.49$ & & \multicolumn{2}{|c|}{ LSD (0.05) Yıl: $0.46^{*}$} & \multicolumn{2}{|c|}{ Çeşit: $0.35^{* *}$} & & & & \\
\hline
\end{tabular}

\section{Koza Sayısı, Koza Ağırlığı ve Koza Kütlü Ağırlığı}

Koza sayısı yönünden, yıl ve uygulama $x$ çeşit interaksiyonunun \% 1 önem düzeyinde istatistiki farklılık gösterdiği ve farklı gruplarda yer aldığı belirlenmiştir (Çizelge 5). Koza sayısı değerinin 2013 yılında 15.50 adet bitki ${ }^{-1}$ ile 2014 yılına göre (11.92 adet bitki ${ }^{-1}$ ) daha yüksek olduğu saptanmıştır. Uygulama x çeşit interaksiyonunda, en fazla koza sayısı GW Teks pamuk çeşidinde ve 6 ton $\mathrm{da}^{-1}$ sığır gübresi uygulamasından (17.36 adet bitki $\left.{ }^{-1}\right)$, en düşük değer ise yine aynı çeşidin 4 ton $\mathrm{da}^{-1}$ gübre 
uygulamasından (11.13 adet bitki ${ }^{-1}$ ) elde edilmiştir. Koza ağırlığı yönünden çeşit farklılığının \%1 düzeyinde önemli olduğu Çizelge 5 'de görülmektedir. GW Teks pamuk çeşidi $8.90 \mathrm{~g}$ koza ağırlığı değeri ile a grubunda yer alırken, Stoneville 468 çeşidi 7.18 g koza ağırlığı değeri ile b grubunda yer almıştır. İki yılın ortalama sonuçlarına göre koza ağırlığı gübre uygulamaları bakımından farksız bulunduğu halde, en fazla koza ağırlığı 6 ton da $^{-1} \mathrm{sığır}$ gübresi uygulamasından ( $8.35 \mathrm{~g}$ ) elde edilmiştir.

Çizelge 5. Koza sayısı, koza ağırlığı ve koza kütlü ağırlı̆ı̆ değerleri

Table 5. The values of number of bolls, boll weight and boll seed cotton weight

\begin{tabular}{|c|c|c|c|c|c|c|c|c|c|c|}
\hline \multirow[b]{2}{*}{$\begin{array}{l}\text { Verim } \\
\text { Unsurları }\end{array}$} & \multirow[b]{2}{*}{ Uygulama } & \multicolumn{3}{|c|}{2013} & \multicolumn{3}{|c|}{2014} & \multicolumn{2}{|c|}{ Ortalama } & \multirow{2}{*}{$\begin{array}{l}\text { Genel } \\
\text { Ort. }\end{array}$} \\
\hline & & GW-Teks & ST468 & Ort. & GW-Teks & ST468 & Ort. & GW-Teks & ST468 & \\
\hline \multirow{8}{*}{$\begin{array}{l}\text { Koza Sayısı } \\
\text { (adet/bitki) }\end{array}$} & Çiftçi Uyg. & 14.93 & 15.53 & 15.23 & 9.60 & 12.00 & 10.80 & $12.26 \mathrm{bc}$ & $13.76 \mathrm{~b}$ & 13,01 \\
\hline & 2 ton/da & 15.53 & 14.73 & 15.13 & 10.86 & 13.46 & 12.16 & $13.20 \mathrm{bc}$ & $14.10 \mathrm{~b}$ & 13,65 \\
\hline & 4 ton/da & 12.13 & 16.80 & 14.46 & 10.13 & 12.13 & 11.13 & $11.13 \mathrm{c}$ & $14.46 \mathrm{~b}$ & 12,80 \\
\hline & 6 ton/da & 19.40 & 16.00 & 17.70 & 15.33 & 11.33 & 13.33 & $17.36 \mathrm{a}$ & $13.66 \mathrm{bc}$ & 15,51 \\
\hline & Kontrol & 14.06 & 15.86 & 14.96 & 11.26 & 13.13 & 12.20 & $12.66 \mathrm{bc}$ & $14.50 \mathrm{~b}$ & 13,58 \\
\hline & Ortalama & 15.21 & 15.78 & & 11.44 & 12.41 & & 13.32 & 14.10 & \\
\hline & Yıl Ort. & \multicolumn{2}{|c|}{$15.50 \mathrm{a}$} & & \multicolumn{2}{|c|}{$11.92 \mathrm{~b}$} & & & & \\
\hline & \multicolumn{2}{|l|}{$C V(\%)=15.60$} & \multicolumn{2}{|c|}{ LSD (0.05) Yıl: $1.26^{* *}$} & \multicolumn{2}{|c|}{ Uyg x Çeşit 2.60** } & & & & \\
\hline \multirow{8}{*}{$\begin{array}{l}\text { Koza } \\
\text { Ağırlığı (g) }\end{array}$} & Çiftçi Uyg. & 9.49 & 6.75 & 8.12 & 9.00 & 7.23 & 8.11 & 9.24 & 6.99 & 8.12 \\
\hline & 2 ton/da & 9.12 & 7.07 & 8.10 & 8.30 & 7.30 & 7.80 & 8.71 & 7.18 & 7.95 \\
\hline & 4 ton/da & 8.92 & 6.92 & 7.92 & 9.03 & 7.43 & 8.23 & 8.98 & 7.17 & 8.07 \\
\hline & 6 ton/da & 8.37 & 7.94 & 8.15 & 9.40 & 7.70 & 8.55 & 8.88 & 7.82 & 8.35 \\
\hline & Kontrol & 8.54 & 6.39 & 7.47 & 8.86 & 7.10 & 7.98 & 8.70 & 6.74 & 7.72 \\
\hline & Ortalama & 8.89 & 7.01 & & 8.92 & 7.35 & & $8.90 \mathrm{a}$ & $7.18 \mathrm{~b}$ & \\
\hline & Yıl Ort. & & 95 & & & & & & & \\
\hline & $C V(\%)=7.96$ & & $S D(0.05)$ & it : $0.33^{* *}$ & & & & & & \\
\hline \multirow{8}{*}{$\begin{array}{l}\text { Koza Kütlü } \\
\text { Ağırlığı (g) }\end{array}$} & Çiftçi Uyg. & $6.51 b c$ & 4.85ıj & 5.68 & $6.50 \mathrm{bc}$ & 5.63 e-h & 6.06 & 6.50 & 5.24 & 5.87 \\
\hline & 2 ton/da & $6.34 b-d$ & $5.07 \mathrm{~g}-\mathrm{j}$ & 5.70 & 6.10 b-e & $5.73 \mathrm{~d}-\mathrm{g}$ & 5.91 & 6.22 & 5.40 & 5.81 \\
\hline & 4 ton/da & $6.23 \mathrm{~b}-\mathrm{e}$ & 5.01hıj & 5.62 & $6.73 a b$ & $5.70 \mathrm{~d}-\mathrm{h}$ & 6.21 & 6.48 & 5.35 & 5.91 \\
\hline & 6 ton/da & $5.84 c-f$ & $5.65 d-h$ & 5.74 & $7.23 \mathrm{a}$ & $5.90 \mathrm{c}-\mathrm{f}$ & 6.56 & 6.53 & 5.77 & 6.15 \\
\hline & Kontrol & $5.89 c-f$ & $4.59 \mathrm{j}$ & 5.24 & $6.50 \mathrm{bc}$ & $5.30 \mathrm{f}-\mathrm{I}$ & 5.90 & 6.19 & 4.94 & 5.57 \\
\hline & Ortalama & 6.16 & 5.03 & & 6.61 & 5.65 & & $6.38 \mathrm{a}$ & $5.34 \mathrm{~b}$ & \\
\hline & Yıl Ort. & & $\mathbf{O b}$ & & 6.1 & & & & & \\
\hline & $C V(\%)=6.82$ & & $S D(0.05)$ & $0.37^{*}$ & Çeşit: $0.21^{* *}$ & & x Çeşit C & & & \\
\hline
\end{tabular}

Koza kütlü ağırlığı yönünden çeşit farklılığının \%1 düzeyinde önemli olduğu, yıl ve yıl $x$ uygulama $x$ çeşit interaksiyonunun ise \% 5 önem düzeyinde istatistiki farklılık gösterdiği belirlenmiştir (Çizelge 5). Çeşitler koza kütlü ağırlığı yönünden farklı istatistiki gruplarda yer almıştır, GW Teks çeşidinin $6.38 \mathrm{~g}$ değeri ile a grubunda yer aldığı görülürken, Stoneville 468 çeşidi 5.34 g değeri ile b grubunda yer almıştır. Yıl farklılığının önemli olduğu görülmüş, 2013 yılında koza kütlü ağırlığının $5.60 \mathrm{~g}$ ve 2014 yılında ise $6.13 \mathrm{~g}$ olduğu belirlenmiştir (Çizelge 5). Yıl x Uygulama $x$ Çeşit interaksiyonu incelendiğinde, en yüksek değerin 2014 yılında GW Teks çeşidinde 6 ton da${ }^{1}$ gübre uygulamasından (6.53 g) elde edildiği, en düşük değerin ise 2013 yılında Stoneville 468 çeşidinde ve çiftçi uygulamasından $(5.24 \mathrm{~g}$ ) elde edildiği saptanmıştır. Bu çalışmada elde edilen verilere göre farklı sığır gübresi uygulamalarının koza sayısı, koza ağırlığı ve koza kütlü ağırlığı üzerine etkili olmadığı belirlenmiştir.
Bitki Boyu, Odun Dalı Sayısı, Meyve Dalı Sayısı, ilk Meyve Dalı Boğum Sayısı ve Toplam Boğum Sayısı

Bitki boyu özelliğinde yıl, uygulama ve yıl $x$ uygulama interaksiyonunun $\% 1$, çeşit farklılığının ise $\% 5$ düzeyinde önemli olduğu saptanmıştır (Çizelge 6). Bitki boyu değerleri uygulamalara, yıllara ve yıl $x$ uygulama interaksiyonuna göre farklı gruplarda yer almıştır. Yıl farklılığının önemli olduğu görülmekte olup, 2013 yılında bitki boyu değerinin $107.70 \mathrm{~cm}, 2014$ yılında ise $81.29 \mathrm{~cm}$ olduğu, 2013 yılında bitkilerin daha uzun boylu olduğu görülmektedir. Denemede bitki boyu değeri uygulamalara bağlı olarak değişiklik göstermiştir. En düşük bitki boyu değeri kontrolde $(87.11 \mathrm{~cm})$ ve yüksek değer ise 2 ton da da $^{-1}$ sığır gübresi uygulamasında (99.88 $\mathrm{cm}$ ) tespit edilmiştir. Çeşitler bitki boyu yönünden farklı gruplarda yer almıştır, GW Teks çeşidi $96.09 \mathrm{~cm}$ ile a grubunda yer alırken, Stoneville 468 çeşidi $(92.90 \mathrm{~cm})$ ile b grubunda yer almıştır. Yıl x uygulama interaksiyonuna bakıldığında en yüksek bitki boyu değerinin 2013 yılında 6 ton da $^{-1}$ (114.93), en düşük değerin ise 2014 yılında 4 
ton $\mathrm{da}^{-1}$ uygulamasından (78.00) elde edildiği belirlenmiştir.

Odun dalı sayısı değerlerinde yıl ve yıl $\mathrm{x}$ uygulama interaksiyonu \%1 düzeyinde önemli bulunmuştur. Yıllara göre çeşitler farklı gruplarda yer almıştır (Çizelge 6). Odun dalı sayısının 2013 yılında (3.17 adet bitki ${ }^{-1}$ ) 2014 yılına göre (5.45 adet bitki $\left.{ }^{-1}\right)$ daha düşük olduğu belirlenmiştir. Yıl $\mathrm{x}$ uygulama interaksiyonuna bakıldığında en yüksek değerin 2014 yılında 2 ton da-1 uygulamasından (6.13 adet bitki $\left.{ }^{-1}\right)$, en düşük değerin ise 2013 yilında kontrol uygulamadan $\left(2.96\right.$ adet bitki $\left.^{-1}\right)$ elde edildiği belirlenmiştir.

Meyve dalı sayısı bakımından yıl, uygulama ve yıl $x$ uygulama interaksiyonunun \%1 düzeyinde önemli olduğu görülmektedir (Çizelge 6). Meyve dalı sayısında yıl farklıığının önemli olduğu, 2013 yılında meyve dalı sayısının 10.88 adet bitki $^{-1}, 2014$ yılında ise 4.35 adet bitki $^{-1}$ olduğu görülmektedir. Meyve dalı sayısı uygulamalara bağlı olarak 7.03 ile 8.23 adet bitki ${ }^{-1}$ arasında değişiklik göstermiştir. En fazla meyve dalı sayısı 2 ton $\mathrm{da}^{-1}$ sığır gübre uygulamasında (8.23 adet bitki ${ }^{-1}$ ) elde edilmiştir. Yıl $x$ uygulama interaksiyonu incelendiğinde en yüksek değerin 2013 yılında 2 ton da ${ }^{-1}$ uygulamasından (12.10 adet bitki ${ }^{-1}$ ) elde edildiği, en düşük değerin ise 2014 yılında çiftçi uygulamasından (4.13 adet bitki ${ }^{-1}$ ) elde edildiği belirlenmiştir.

Çizelge 6. Bitki boyu, odun dalı sayısı ve meyve dalı sayısı değerleri

Table 6. The values of plant height, number of monopodial branches and number of sympodial branches

\begin{tabular}{|c|c|c|c|c|c|c|c|c|c|c|}
\hline \multirow[b]{2}{*}{$\begin{array}{l}\text { Verim } \\
\text { Unsurları }\end{array}$} & \multirow[t]{2}{*}{ Uygulama } & \multicolumn{3}{|c|}{2013 Yılı } & \multicolumn{3}{|c|}{2014 Yılı } & \multicolumn{2}{|c|}{ Ortalama } & \multirow{2}{*}{$\begin{array}{l}\text { Genel } \\
\text { Ort. }\end{array}$} \\
\hline & & GW-Teks & ST468 & Ort. & $\begin{array}{l}\text { GW- } \\
\text { Teks }\end{array}$ & ST468 & Ort. & $\begin{array}{l}\text { GW- } \\
\text { Teks }\end{array}$ & ST468 & \\
\hline \multirow{8}{*}{$\begin{array}{l}\text { Bitki Boyu } \\
\text { (cm) }\end{array}$} & Çiftçi & 117.33 & 110.80 & 114.06 a & 82.27 & 78.80 & 80.53 ef & 99.80 & 94.80 & $97.30 \mathrm{a}$ \\
\hline & 2 ton/da & 118.06 & 108.73 & $113.40 \mathrm{a}$ & 85.53 & 87.20 & $86.36 \mathrm{~d}$ & 101.80 & 97.97 & $99.88 \mathrm{a}$ \\
\hline & 4 ton/da & 99.93 & 101.20 & $100.56 \mathrm{~b}$ & 77.53 & 78.46 & $78.00 \mathrm{f}$ & 88.73 & 89.83 & $89.28 b$ \\
\hline & 6 ton/da & 121.13 & 108.73 & $114.93 \mathrm{a}$ & 86.13 & 79.66 & $82.90 \mathrm{de}$ & 103.63 & 94.20 & $98.91 \mathrm{a}$ \\
\hline & Kontrol & 96.33 & 94.80 & $95.56 \mathrm{c}$ & 76.67 & 80.67 & 78.66 ef & 86.50 & 87.73 & $87.11 b$ \\
\hline & Ortalama & 110.56 & 104.85 & & 81.62 & 80.96 & & $96.09 \mathrm{a}$ & $92.90 \mathrm{~b}$ & \\
\hline & Yıl Ort. & \multicolumn{2}{|c|}{$107.70 \mathrm{a}$} & & \multicolumn{3}{|c|}{$81.29 \mathrm{~b}$} & & & \\
\hline & $C V(\%)=5.09$ & \multicolumn{3}{|c|}{ LSD (0.05) Yıl: $1.91 * *$} & Uyg :3.01** & \multicolumn{2}{|c|}{ YIl x Uyg: 4.26** } & Çeşit: 2.57* & & \\
\hline \multirow{8}{*}{$\begin{array}{l}\text { Odun Dalı } \\
\text { Sayısı } \\
\text { (adet/bitki) }\end{array}$} & Çiftçi & 2.80 & 3.33 & $3.06 \mathrm{~d}$ & 5.73 & 5.80 & $5.76 a b$ & 4.27 & 4.57 & 4.42 \\
\hline & 2 ton/da & 3.33 & 2.73 & $3.03 \mathrm{~d}$ & 6.20 & 6.06 & $6.13 \mathrm{a}$ & 4.76 & 4.40 & 4.58 \\
\hline & 4 ton/da & 3.66 & 3.60 & $3.63 \mathrm{~d}$ & 4.80 & 4.66 & $4.73 c$ & 4.23 & 4.13 & 4.18 \\
\hline & 6 ton/da & 3.40 & 2.93 & $3.16 \mathrm{~d}$ & 5.60 & 4.53 & $5.06 \mathrm{bc}$ & 4.50 & 3.73 & 4.11 \\
\hline & Kontrol & 2.46 & 3.46 & $2.96 \mathrm{~d}$ & 5.46 & 5.66 & $5.56 \mathrm{ab}$ & 3.97 & 4.57 & 4.27 \\
\hline & Ortalama & 3.13 & 3.21 & & 5.56 & 5.34 & & 4.34 & 4,28 & 4.42 \\
\hline & Yıl Ort. & \multicolumn{3}{|c|}{$3.17 \mathrm{~b}$} & \multicolumn{3}{|c|}{$5.45 a$} & & & \\
\hline & \multicolumn{2}{|l|}{$C V(\%)=15.31$} & $0.05) Y_{1}$ & Yıl: $0.31 * *$ & \multicolumn{3}{|c|}{ Yıl X Uyg: 0.70** } & & & \\
\hline & Çiftçi & 10.93 & 11.46 & $11.20 \mathrm{~b}$ & 4.13 & 4.13 & $4.13 \mathrm{~d}$ & 7.53 & 7.80 & $7.66 \mathrm{~b}$ \\
\hline Meyve Dalı & 2 ton/da & 12.53 & 11.66 & $12.10 \mathrm{a}$ & 4.33 & 4.40 & $4.36 \mathrm{~d}$ & 8.43 & 8.03 & $8.23 \mathrm{a}$ \\
\hline Sayısı & 4 ton/da & 10.06 & 9.73 & $9.90 \mathrm{c}$ & 4.20 & 4.13 & $4.16 \mathrm{~d}$ & 7.13 & 6.93 & $7.03 c$ \\
\hline \multirow[t]{5}{*}{ (adet/bitki) } & 6 ton/da & 12.40 & 10.66 & $11.53 \mathrm{ab}$ & 5.00 & 4.20 & $4.60 \mathrm{~d}$ & 8.70 & 7.43 & $8.06 a b$ \\
\hline & Kontrol & 10.20 & 9.20 & $9.70 \mathrm{c}$ & 4.66 & 4.33 & $4.50 \mathrm{~d}$ & 7.43 & 6.76 & $7.10 \mathrm{c}$ \\
\hline & Ortalama & 11.22 & 10.54 & & 4.46 & 4.24 & & 7.84 & 7.39 & \\
\hline & Yıl Ort. & \multicolumn{3}{|c|}{10.88 a } & \multicolumn{3}{|c|}{$4.35 \mathrm{~b}$} & & & \\
\hline & $C V(\%)=13.51$ & \multicolumn{3}{|c|}{ LSD (0.05) YıI: 0.33** } & Uyg :0.54* & & g: $0.75^{* *}$ & & & \\
\hline
\end{tabular}

Illk meyve dalı boğum sayısı bakımından, yıl \%1 düzeyinde, çeşit ve uygulama $x$ çeşit interaksiyonu ise $\% 5$ düzeyinde önemli bulunmuştur (Çizelge 7). GW Teks çeşidi 3.52 adet bitki ${ }^{-1}$ değeri ile a grubunda, Stoneville 468 çeşidi ise 3.21 adet bitki ${ }^{-1}$ değeri ile $b$ grubunda yer almıştır. Illk meyve dalı boğum sayısı yıllara göre değişiklik göstermiş olup, 2013 yılında 3.66 adet bitki ${ }^{-1}, 2014$ yılında ise 3.07 adet bitki ${ }^{-1}$ değeri elde edilmiştir.

Toplam boğum sayısı yönünden yıl ve uygulamanın \%1 düzeyinde, uygulama $x$ çeşit interaksiyonunun ise $\% 5$ düzeyinde önemli olduğu, yıl ve gübre uygulamalarına göre farklı gruplarda yer aldığı saptanmıştır (Çizelge 7).
Çeşitlerin toplam boğum sayıs 2013 yılında 16.14 adet bitki $^{-1}, 2014$ yılında ise 12.74 adet bitki ${ }^{-1}$ olarak saptanmış, birinci yıl değeri daha yüksek bulunmuştur. Gübre uygulamaları toplam boğum sayısı üzerine etkili olup, en yüksek değer 2 ton da-1 (15.45 adet bitki $\left.{ }^{-1}\right)$, en düşük değer ise 6 ton da ${ }^{-1}$ gübre uygulamasından (13.26 adet bitki $^{-1}$ ) elde edilmiştir. Uygulama $x$ çeşit interaksiyonu önemli olup, en yüksek değer GW Teks çeşidinin 2 ton da $^{-1}$ (15.60 adet bitki $\left.{ }^{-1}\right)$, en düşük değer ise aynı çeşidin 4 ton da ${ }^{-1}$ gübre uygulamasından (13.20 adet bitki ${ }^{-1}$ ) elde edildiği saptanmıştır.

$\mathrm{Bu}$ çalışmada gübre uygulamalarına göre bitki boyu, 
meyve dalı sayısı ve toplam boğum sayısı farklı bulunduğu halde, odun dalı sayısı ve ilk meyve dalı sayısı farksız bulunmuştur. Bu konuda yapılan bir çalışmada, organik gübrenin pamukta bitki boyu, ilk meyve dalı boğum sayısı, odun ve meyve dalı sayısında önemli bir farkılık yaratmadığı belirtilmektedir (Islam ve ark., 2014).

Çizelge 7. İlk meyve dalı boğum sayısı ve toplam boğum sayısı değerleri

Table 7. The values of number of node to the first fruiting branch and total number of nodes per plant

\begin{tabular}{|c|c|c|c|c|c|c|c|c|c|c|}
\hline \multirow[b]{2}{*}{$\begin{array}{l}\text { Verim } \\
\text { Unsurları }\end{array}$} & \multirow[t]{2}{*}{ Uygulama } & \multicolumn{3}{|c|}{2013 Yılı } & \multicolumn{3}{|c|}{2014 Yılı } & \multicolumn{2}{|c|}{ Ortalama } & \multirow{2}{*}{$\begin{array}{l}\text { Genel } \\
\text { Ort. }\end{array}$} \\
\hline & & $\begin{array}{l}\text { GW- } \\
\text { Teks }\end{array}$ & ST468 & Ort. & $\begin{array}{l}\text { GW- } \\
\text { Teks }\end{array}$ & ST468 & Ort. & GW-Teks & ST468 & \\
\hline \multirow{8}{*}{$\begin{array}{l}\text { İlk Meyve Dalı } \\
\text { Boğum Sayısı } \\
\text { (adet/bitki) }\end{array}$} & Çiftçi Uyg. & 4.40 & 3.20 & 3.80 & 4.06 & 3.73 & 3.90 & $4.23 \mathrm{a}$ & $3.46 \mathrm{bc}$ & 3.85 \\
\hline & 2 ton/da & 3.86 & 3.93 & 3.90 & 3.26 & 3.06 & 3.16 & $3.56 \mathrm{~b}$ & $3.50 \mathrm{bc}$ & 3.53 \\
\hline & 4 ton/da & 3.93 & 2.86 & 3.40 & 2.80 & 2.33 & 2.56 & $3.36 \mathrm{bc}$ & $2.60 \mathrm{~d}$ & 2.98 \\
\hline & 6 ton/da & 3.40 & 4.06 & 3.73 & 2.53 & 2.86 & 2.70 & $2.96 \mathrm{~cd}$ & $3.46 \mathrm{bc}$ & 3.21 \\
\hline & Kontrol & 4.00 & 2.93 & 4.46 & 2.93 & 3.13 & 3.03 & $3.46 \mathrm{bc}$ & $3.03 \mathrm{bcd}$ & 3.25 \\
\hline & Ortalama & 3.92 & 3.40 & & 3.12 & 3.02 & & $3.52 \mathrm{a}$ & $3.21 \mathrm{~b}$ & \\
\hline & Yıl Ort. & \multicolumn{2}{|c|}{$3.66 \mathrm{a}$} & & \multicolumn{2}{|c|}{$3.07 \mathrm{~b}$} & & & & \\
\hline & \multicolumn{2}{|l|}{$C V(\%)=13.69$} & $L S D(0.05)$ & YIl: $0.35^{* *}$ & \multicolumn{2}{|c|}{ Çeşit:0.22* } & \multicolumn{2}{|c|}{ Uyg x Çeşit: 0.54* } & & \\
\hline \multirow{8}{*}{$\begin{array}{l}\text { Toplam } \\
\text { Boğum Sayısı } \\
\text { (adet/bitki) }\end{array}$} & Çiftçi Uyg. & 16.53 & 17.26 & 16.90 & 13.13 & 13.60 & 13.36 & $14.83 a b c$ & $15.43 \mathrm{a}$ & $15.13 \mathrm{a}$ \\
\hline & 2 ton/da & 17.06 & 16.53 & 16.80 & 14.13 & 14.06 & 14.10 & $15.60 \mathrm{a}$ & $15.30 \mathrm{ab}$ & $15.45 \mathrm{a}$ \\
\hline & 4 ton/da & 14.80 & 15.93 & 15.36 & 11.60 & 11.13 & 11.36 & $13.20 \mathrm{~d}$ & $13.53 \mathrm{~d}$ & $13.36 \mathrm{c}$ \\
\hline & 6 ton/da & 17.20 & 15.40 & 16.30 & 12.93 & 11.53 & 12.23 & $15.06 \mathrm{ab}$ & $13.46 \mathrm{~d}$ & $14.26 \mathrm{~b}$ \\
\hline & Kontrol & 14.86 & 15.86 & 15.36 & 12.60 & 12.66 & 12.63 & $13.73 \mathrm{~cd}$ & $14.26 \mathrm{bcd}$ & $14.00 \mathrm{bc}$ \\
\hline & Ortalama & 16.09 & 16.20 & & 12.88 & 12.60 & & 14.48 & 14.40 & \\
\hline & Yıl Ort. & \multicolumn{2}{|c|}{$16.14 \mathrm{a}$} & & \multicolumn{2}{|c|}{$12.74 \mathrm{~b}$} & & & & \\
\hline & $C V(\%)=6.30$ & \multicolumn{2}{|c|}{$L S D(0.05)$} & Yıl: $0.43 * *$ & \multicolumn{2}{|c|}{ Uyg :0.67** } & Jyg x Çeşi & $1.08^{*}$ & & \\
\hline
\end{tabular}

\section{Korelasyon Analizi}

Yeşil aksam ve gövde kesiti hastalık indeksleri ile incelenen verim ve verim parametreleri arasındaki korelasyon değerleri Çizelge 8'de verilmiştir. Kozaların \% 5-10 açtığı dönemdeki hastalık şiddeti ile bitki boyu, ilk meyve dalı boğum sayısı, meyve dalı sayısı, koza sayısı, tek koza kütlü ağırlığı ve 100 tohum ağırlığı arasında önemli ve negatif yönde korelasyonun bulunduğu; verim, odun dalı sayısı ve ilk el kütlü oranı ile önemli ve pozitif yönde bir korelasyonun bulunduğu saptanmıştır. Hastalık şiddeti arttığında bitki boyu, ilk meyve dalı boğum sayısı, meyve dalı sayısı, koza sayısı, tek koza kütlü ağırlığı ve 100 tohum ağırlığı değerleri azalmıştır. Hastalık şiddeti ile verim, odun dalı sayısı ve ilk el kütlü oranı artmıştır. Bu durum hastalık şiddeti ile bitkilerin daha erken hasada geldiğini göstermektedir. Ancak hastalık şiddeti ile verim arasında pozitif bir korelasyonun bulunması \% 5-10 koza açma döneminde yapılan hastalık değerlendirmelerinin hastalığın etkisini belirlemek için erken bir dönem olduğu izlenimini vermektedir.

Kozaların \% 50-60 açtığı dönemdeki hastalık şiddeti ile bitki boyu, meyve dalı sayısı, tek koza ağırlığı, 100 tohum ağırlığı arasında önemli ve negatif, odun dalı sayısı, verim ve ilk el kütlü oranı arasında önemli ve pozitif yönde bir korelasyonun bulunduğu belirlenmiştir. Hastalık şiddeti ile bitki boyu, meyve dalı sayısı, tek koza ağırlığı, 100 tohum ağırlığı azalmış, verim, odun dalı sayısı ve ilk el kütlü oranı artmıştır. Bu durum hastalık şiddeti ile bitkilerin daha erken hasada geldiğini ve ilk el kütlü oranı değerinin yükseldiğini göstermektedir. Hastalık şiddeti ile verim arasında pozitif bir korelasyonun bulunması bitkilerin hastalığa yakalanma zamanlarının önemli olduğu izlenimini vermektedir.

Gövde kesiti hastalık indeksi ile bitki boyu, meyve dalı sayısı, tek koza ağırlığı arasında önemli ve negatif, odun dalı sayısı, ilk el kütlü oranı, yeşil aksam hastalık indeksleri (\% 5-10 ve \%50-60 koza açma dönemi) arasında önemli ve pozitif yönde korelasyonun bulunduğu belirlenmiştir. Gövde kesiti hastalık indeksi bitki boyu, meyve dalı sayısı ve tek koza ağırlığı değerlerinin azalmasına, odun dalı sayısı ile ilk el kütlü oranı değerinin artmasına neden olmuştur.

Pamuk solgunluk hastalığı konusunda yapılan çalışmalarda, hastalık ile verim ve verim parametreleri arasında ilişkiler olduğu belirlenmiştir. Nitekim Kaliforniya'da pamuk solgunluğu entegre mücadele konusunda yapılan çalışmada, lif verimi ve lif randımanı ile yapraktan \% solgunluk arasında çok yüksek bir negatif korelasyon bulunduğu, bir populasyondaki solgun bitki yüzdesi artarken lif veriminin azaldığı saptanmıştır (ElZik, 1985).

Ülkemizin Ege bölgesinde yapılan çalışmalarda, solgunluk hastalığı ile kütlü pamuk verimi ve 100 tohum 
ağırlığı arasında negatif yönde önemli korelasyonlar olduğu bildirilmektedir (Kaymak ve ark.,1976; Yelin ve Erşan, 1985; Erdoğan ve Benlioğlu, 2007). Güneydoğu Anadolu bölgesinde yapılan çalışmada ise hastalık indeksi ile bitki boyu, odun dalı, koza ağırlığı ve kütlü verimi arasında önemli ve olumsuz; hastalık indeksi ile meyve dalı ve koza sayısı arasında olumlu bir ilişki olduğu belirlenmiştir. (Erdemci ve ark., 2003). Zira yapılan başka bir çalışmada, hastalık şiddeti ile 100 tohum ağırlığı arasında negatif bir ilişkinin olduğu, hastalık şiddetinin artması ile tohum ağırlığının azaldığı bildirilmiştir (Sakcı, 2015). Verticillium hastalığının kütlü pamuk veriminde \%7.86, lif veriminde \%6.73 oranında azalışa yol açtığı, çeşitlerin hastalığa yakalanma zamanlarının verim üzerinde önemli gösterge olduğu bildirilmektedir (Karademir ve ark., 2012).

Çizelge 8. Hastalık şiddeti ile incelenen diğer özellikler arasındaki korelasyon analiz tablosu

Table 8. The table of correlation analysis between disease severity index and other traits Multivariate Pairwise Correlations

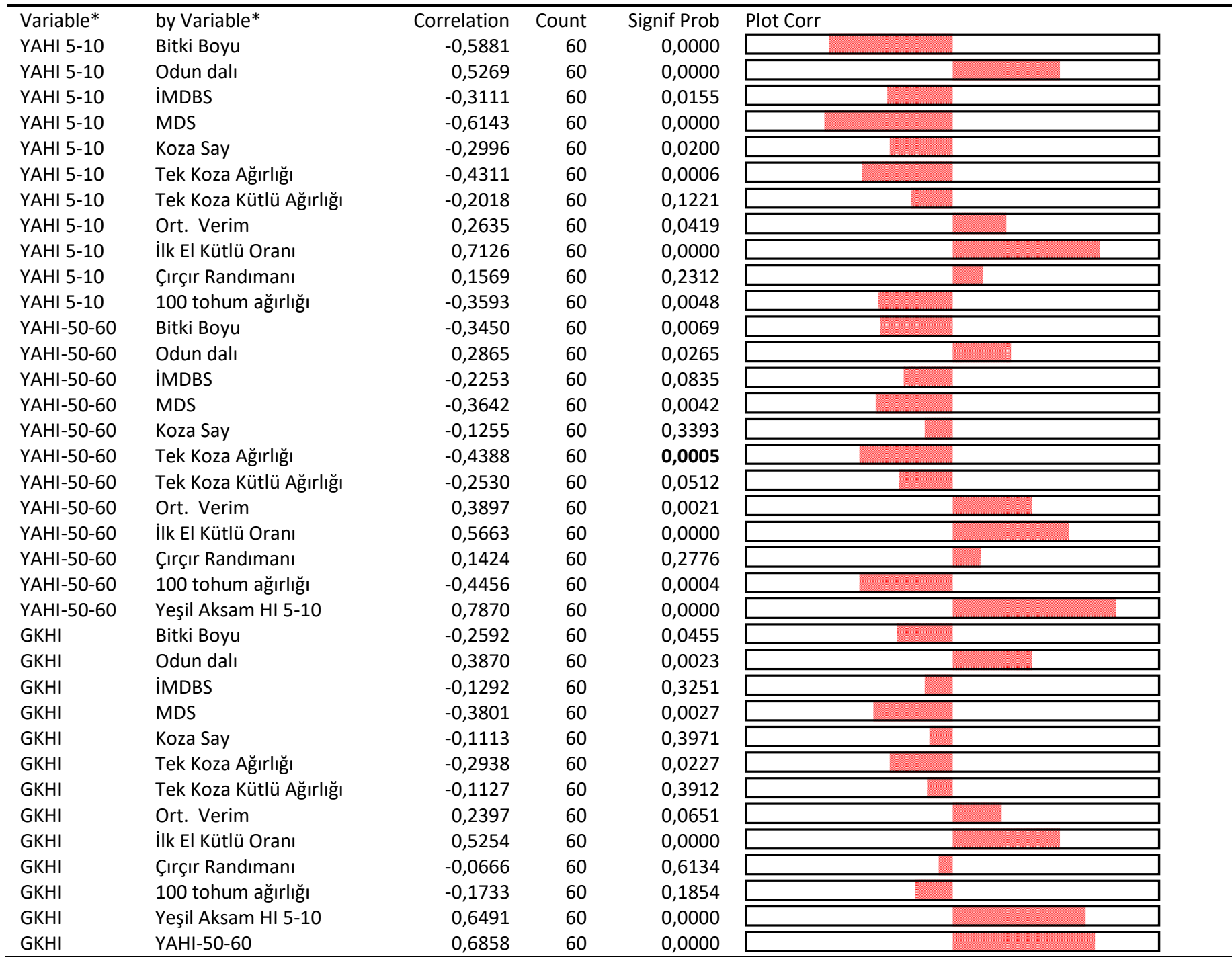

\section{Sonuç}

Sonuç olarak iki farklı pamuk çeşidi ve farklı sığır gübresi dozları kullanılarak yürütülen bu çalışmada çeşitlere ve sığır gübresi dozlarına göre hastalık şiddetinin farklı olduğu ortaya konulmuş, çiftçi uygulamasına göre 2 ton $\mathrm{da}^{-1}, 4$ ton $\mathrm{da}^{-1}$ ve 6 ton $\mathrm{da}^{-1}$ gübre uygulamalarının verimi daha yüksek bulunmuş ve en yüksek verim 6 ton da $^{-1}$ gübre uygulamasıyla elde edilmiştir. Ülkemizde pamuk solgunluk hastalığı konusunda çiftlik gübresinin etkisi konusunda çok az sayıda çalışma yapılmıştır. Kontrollü koşullarda özellikle organik pamuk üretiminin gelişmesi ve teşvik edilmesi için buna benzer çalışmaların yapılmasının faydalı olacağı düşünülmektedir. 


\section{ÖZET}

Amaç: Bu çalışma, sığır gübresi uygulamalarının (2, 4 ve 6 ton $\mathrm{da}^{-1}$ sığır gübresi, çiftçi uygulaması ve kontrol) pamuk solgunluk hastalığı ile verim ve verim parametrelerine etkisini belirlemek amacıyla yürütülmüştür.

Yöntem ve Bulgular: Araştırma, Diyarbakır Bismil'de hastalık etmeni $V$. dahliae fungusu ile doğal bulaşık olan bir üretici tarlasında, tesadüf bloklarında bölünmüş parseller deneme desenine göre üç tekrarlamalı olarak yürütülmüştür. Çalışmada iki pamuk çeşidi (solgunluk hastalığına karşı tolerant GW Teks ve orta derecede tolerant Stoneville 468) materyal olarak kullanılmıştır. Deneme alanında gübrelemeden önce toprak örnekleri alınarak hastalık etmeninin inokulum yoğunluğu belirlenmiştir. Hastalık şiddeti, yeşil aksam ve gövde kesiti değerlendirmesine göre hesaplanmıştır. Denemenin yürütüldüğü alanda 2013 yılında bir gram toprakta 75 adet mikrosklerot (ms) bulunduğu saptanmıştır. İkinci yılda 2 ve 4 ton da $^{-1}$ sığır uygulaması hariç diğer parsellerde seklerot yoğunluğunda bir artış görülmüştür. Varyans analiz sonuçlarına göre hastalık şiddeti, gübre uygulamaları, pamuk çeşitleri ve yıllar arasındaki fark istatistiki olarak önemli bulunmuştur. En düşük hastalık şiddeti yeşil aksam değerlendirmesinde 2 ton $\mathrm{da}^{-1}$ (1.48), gövde kesitinde ise 4 ton $\mathrm{da}^{-1}$ (1.58) uygulamasında saptanmıştır. ìki yıllık sonuçlar incelendiğinde, GW Teks çeşidinin hastalık şiddeti Stoneville 468'e göre daha düşük değer göstermiştir. Sığır gübresi uygulamalarına göre kütlü pamuk verimi, çırçır randımanı, bitki boyu, meyve dalı sayısı ve toplam boğum sayısında önemli istatistiki farklılıklar elde edilirken, 100 tohum ağırlığı, odun dalı sayısı, koza ağırlığı, koza kütlü ağırlığı ve ilk meyve dalı boğum sayısında ise farklılıklar önemsiz bulunmuştur. En yüksek pamuk verimi $304.61 \mathrm{~kg} \mathrm{da}^{-1}$ ile 6 ton da ${ }^{-1}$ sığır gübresi uygulamasından elde edilmiştir. GW Teks ve Stoneville 468 çeşitlerinin verimleri sırasıyla $233.15 \mathrm{~kg} \mathrm{da}^{-1}$ ve $301.52 \mathrm{~kg} \mathrm{da}^{-1}$ olarak belirlenmiştir.

Genel Yorum: Sığır gübresi uygulamasının Verticillium solgunluğunu baskıladığı ve verimi olumlu yönde etkilediği belirlenmiştir.

Çalışmanın Önemi ve Etkisi: Sığır gübresi uygulamasıyla pamukta verim artışının yanısıra Verticillium dahliae Kleb. in neden olduğu solgunluk hastalığının da kontrol altına alınabileceği yönünde elde edilen bulgular, araştırma sonuçlarının hastalığın görüldüğü pamuk üretim alanları için önemli etkisinin olacağı yönündedir.

Anahtar Kelimeler: Pamuk, solgunluk, sığır gübresi, verim, Verticillium dahliae Kleb.

\section{TEŞEKKÜR}

Projeye danışmanlık yaparak bilgi ve deneyimleriyle katkı sağlayan Sayın Prof. Dr. Abuzer SAĞIR'a, tarlasını deneme için tahsis eden, denemenin her aşamasında yardımlarını esirgemeyen Sayın Fuat AKYILDIZ'a teşekkür ederiz. Projenin finansal desteği (TAGEM-BS-12/0402/02-12) no'lu proje ile TAGEM tarafından sağlanmıştır. Bu nedenle Tarımsal Araştırmalar ve Politikalar Genel Müdürlüğüne (TAGEM) sağladığı destekten dolayı teşekkür ederiz.

\section{ÇIKAR ÇATIŞMA BEYANI}

Makale yazarları aralarında herhangi bir çıkar çatışması olmadığını beyan ederler.

\section{ARAŞTIRMACILARIN KATKI ORANI BEYANI}

Yazarlar makaleye eşit oranda katkı sağlamış olduklarını beyan ederler. Çalışmanın lif kalite analizleri ve elde edilen bulgular 2019 yılında Bitki Koruma Bülteninde yayınlanmıştır.

\section{KAYNAKLAR}

Anonim (2000) Pamukta Entegre Mücadele Teknik Talimatı, Tarım ve Köyişleri Bakanlığı, TAGEM, Bitki Sağlığı Araştırmaları Daire Başkanlığı, Ankara, s 14-16. Anonim (2008) Zirai Mücadele Teknik Talimatları Cilt 2. Tarım ve Köyişleri Bakanlığı, Tarımsal Araştırmalar Genel Müdürlüğü, Ankara, 260 s.

Anonim (2018) Gümrük ve Ticaret Bakanlığı Kooperatifçilik Genel Müdürlüğü, 2017 Yılı Pamuk Raporu, Mart, 40 s., http://koop.gtb.gov.tr/data (Erişim Tarihi: 25 Ekim 2018)

Agrios GN (1997) Plant Pathology. Fourth Edition. Academic Press, 635 pp.

Aygün H (1992) Pamuk (G. hirsutum L.)'da Yeşil Gübrelerin Etkileri Üzerinde Araştırmalar. Doktora Tezi, Ege Üniversitesi, Fen Bil. Ens., Bornova-Izmir, 89 s.

Bejarano-Alcazar J, Melero-Vara JM, Blanco-Lopez MA, Jımenez-Diaz RM (1995) Influence of Inoculum Density of Defoliatingand Non defoliating Pathotypes of $V$. dahliae on Epidemics of Verticillium wilt of Cotton in Southern Spain. Phytopathology 85: 14741481.

Blaise D, Singh JV, Bonde AN, Tekale KU (2005) Effects of farmyard manure and fertilizers on yield, fibre quality and nutrient balance of rainfed cotton (Gossypium hirsutum). Bioresource Tech. 96(3): 345-9. 
Bora T (1975) Effects of Alfalfa and its Rhizosphere on Cotton Wilt Fungus, Verticillium dahliae Kleb. J. Turkish Phytopath. 4(1): 1-6.

Çopur O, Birgül iH (2017) Harran ovası koşullarında bazı pamuk (Gossypium hirsutum L.) çeşitlerinde fenolojik özelliklerin belirlenmesi. Harran Tarım ve Gıda Bil. Derg. 21(2): 196-208.

Derviş S, Biçici M (2005) Pamukta verticillium solgunlugunu azaltmak için kolza (Brassica napus L.), fig (Vicia sativa L.) ve bakla (Vicia faba L.) yeşil gübre uygulamaları. GAP IV. Tarım Kongresi, Eylül 21-23, Şanlıurfa, Türkiye. 305-310.

Derviş S, Yetişir H, Tok FM (2008) Türkiye'de bazı sebze türlerinde Verticillium Solgunluğu. VII. Sebze Tarımı Sempozyumu Bildirileri, Ağustos 26-29, Yalova, Türkiye, s 101.

El-Zik MK (1985) Integrated Control of Verticillium wilt of Cotton. Plant Dis. 69(12): 1025-1032.

Erdemci i, Sağır A (2001) Pamuk ekim zamanları ile solgunluk hastalığı (Verticillium dahliae Kleb.) arasındaki ilişkinin ve bunun verime olan etkisinin belirlenmesi. Türkiye IX. Fitopatoloji Kongresi, Eylül 38, Tekirdağ, Türkiye, 284-290.

Erdemci i, Sağır A, Başbağ S (2003) Ekim zamanları ile pamuğun ( $G$. hirsutum) bazı agronomik özellikleri ve solgunluk hastalığı (Verticillium dahliae) arasındaki ilişkinin belirlenmesi. Türkiye 5. Tarla Bitkileri Kongresi, Ekim 13-17, Diyarbakır, Türkiye, 655-659.

Erdoğan O, Sezener V, Özbek N, Bozbek T, Yavaş I, Ünay A (2006) The effects of Verticillium wilt (Verticillium dahliae Kleb.) on cotton yield and fiber quality. Asian J. Plant Sci. 5(5): 867-870.

Erdoğan O, Dündar H (2007) Bazı Pamuk Çeşitlerinin Verticillium Solgunluk Hastalığı Etmeni (Verticillium dahliae Kleb.)'ne Karşı Duyarlııklarının Belirlenmesi. Türkiye II: Bitki Koruma Kongresi, Ağustos 27-29, Isparta, Türkiye. $93 \mathrm{~s}$.

Erdoğan O, Benlioğlu K (2007) Fluoresan Pseudomonasların Pamukta Verticillium Solgunluğu (V. Dahliae Kleb.)'na ve Bitki Gelişimine Etkileri. Doktora Tezi, ADÜ Fen Bil. Ens. Fitopatoloji ABD, Aydın, $121 \mathrm{~s}$.

Erdoğan O, Göre ME, Özbek N (2012) Yeşil gübre uygulamalarının organik pamuk üretiminde solgunluk hastalığı (Verticillium dahliae Kleb.)'na ve verime etkileri. Bitki Koruma Bülteni 52(1): 81-91.

Erwin DC, Tsoti SD, Khan RA (1976) Reduction of severity of Verticillium wilt of cotton by the growth retardant tributyl (5-chloro-2-thienyl methyl) phosphonium chloride. Pytopathology 66: 106-110.
Esentepe M, Karcilığlu A, Sezgin E (1972) The first report of Verticillium wilt of sesame and okra in Turkey. J. Turkish Phytopath. 1(3): 127- 129.

Esentepe M (1979) Adana ve Antalya illerinde pamuklarda görülen solgunluk hastalığının etmeni, yayılışı, kesafeti ve zarar derecesi ile ekolojisi üzerinde araştırmalar. İzmir Bölge Zirai Mücadele Araştırma Enstitüsü Müdürlüğü Araştırma Eserleri Serisi, Yayın No:32, $45 \mathrm{~s}$.

Gaerli H, Alhafeth A, Alzoubi MA, Ramadan Y, Alshebli K, Alkuto A, Fatoom M (2015) The Effect of Animal Manure and Green Manure on Soil Properties and Crop Productivity in Gypsum Soil. Jordan J. Agri. Sci. ISSN 1815-8625.

Gencer O, Coşkun TF, Tarımer N, Josef A (1998) Adana ili I. Tarım Şurası, Pamuk Tarımı Alt Komisyon Raporu, Adana.

Godoy A, Palomo GA, Garcia CEA (1995) Performance of new cotton cultivars on Verticillium dahliae Kleb. Infested soils at Camorca Lagunera, Mexico. Proceedings belt wide Cotton Conferences, January 4-7, 2001, San Antonio TX, USA. 498-500 p.

Fard HM, Shahram N, Saied S (2005) Study on the effect of animal manures on soil borne diseases of cotton. http://agris.fao.org/agris-

search/search.do?recordID=IR2007000988

(Erişim tarihi: 19.11.2018)

Harem E (2014) Türkiye Pamuk Çeşit Katoloğu. Pamuk Araştırma İstasyonu Müdürlüğü Yayın No:14.

Islam KM, Khalequzzaman, Hassan MK, Kaikobad M (2014) Effect of organic and inorganic source of $\mathrm{N}$ and cotton yield. Annual Research Report. Cotton Development Board, Ministry of Agriculture, Bangladesh, 131-142.

İyriboz N (1941) Mahsul Hastalıkları, Ziraat Vekaleti Neşriyatı Umum No: 237.

Joaquim TR, Rowe RC (1990) Reassessment of vegetative compatibility relationships among strains of Verticillium dahliae using nitrate-nonutilizing mutants. Phytopathology 80: 1160-1166.

Kabir Z, Bhat RG, Subbarao KV (2004) Comparison of media for recovery of Verticillium dahliae from soil. Plant Dis. 88: 49-55.

Karaca I, Karcilığlu A, Ceylan S (1971) Wilt disease of cotton in the Eagan Region of Turkey. J. Turkish. Phytopath. 1(1): 4-11.

Karademir Ç, Karademir E, Doran i, Altıkat A (2005) Diyarbakır Ekolojik Koşullarında Farklı Azot ve Fosfor Uygulamalarının Pamukta Verim ve Lif Teknolojik Özelliklere Etkisi. GOP Zir. Fak. Derg. 22(12): 55-61. 
Karademir E, Karademir Ç, Ekinci R, Baran B, Sağır A (2012) Effect of Verticillium dahliae Kleb. on Cotton Yield and Fiber Technological Properties. International Journal of Plant Production 6(4): 387408.

Karademir Ç, Karademir E, Ekinci R, Sevilmiş U (2015) İleri Generasyondaki pamuk (Gossypium hirsitum L.) hatlarında verim ve lif kalite özelliklerinin belirlenmesi. Türkiye Tar. Araş. Derg. 2(2): 100-107.

Karademir Ç, Karademir E, Sevilmiş U (2017) Bazı pamuk (Gossypium hirsitum L.) genotiplerinin verim ve lif teknolojik özellikleri bakımından değerlendirilmesi. YYÜ Tar.Bil. Derg. 27(2): 183-191.

Karcılığlu A, Sezgin E, Esentepe M (1985) Üre gübrelemesi ile pamuklarda verticillium solgunluğunu önleme imkanları üzerinde araştırmalar. TÜBITAK Doğa Bil.Derg. Seri D 2(9): 359-366.

Kaymak F, Şimşek M, Ünal M (1976) Pamuk Çeşitlerinin Solgunluk Hastalığına Mukavemetlerinin Tespiti. Proje No:62/105-814-B1.S:195 Nazilli Bölge Pamuk Araştırma Enstitüsü Araştırma Proje ve Sonuçları, 195-205 s.

Kerkeni A, Remadi MD, Tarchoun N, Khedher MB (2007) In vitro assessment of the anti fungal activity of several compost extracts obtained from compoted animal manure mixtures. Int. J. Agri. Res. 2(9): 786794.

Kocatürk S, Karcılıoğlu A (1979) Ege Bölgesinde Verticillium spp. fungusunun konukçuları ve türlerinin tespiti üzerinde çalışmalar. Bitki Koruma Bülteni 19(4): 237-242.

Kurt Ş, Bicici M (1998) Development of $V$. dahliae in cotton plants grown in Çukurova and reaction of some cultivars to wilt. Proceedings of the World Cotton Research Conference-2, September 6-12, Greece. pp 919-922.

Nemli T (2003) Pamuk Hastalıkları ve Savaşım Yöntemleri. Pamukta Eğitim Semineri, Ekim 14-17, İzmir, Türkiye. 103-111 s.

Rossbauer G, Zwack F (1982) Chopped Hop Bines-Waste or Valuable Fertilizer. Hopfen- Rundscha 33(22): 464472.

Sağır A, Tatlı F, Gürkan B (1995) Güneydoğu Anadolu Bölgesinde pamuk ekim alanlarında görülen hastalıklar üzerinde çalışmalar. GAP Bölgesi Bitki Koruma Sorunları ve Çözüm Önerileri Sempozyumu, Nisan 27-29, Şanlıurfa, Türkiye. 5-9 s.

Sağır A, Başbağ S (1998) Pamukta Solgunluk Hastalığı (V. dahliae Kleb.) Üzerine Damla Sulama Yönteminin Etkisi. Türkiye VIII. Fitopatoloji Kongresi, 18-22, Ekim, Ankara, 143-148.
Sağır A, Aydın MH (2001) Bazı pamuk çeşitlerinin solgunluk hastalığı (Verticillium dahliae Kleb.)'na karşı reaksiyonlarının belirlenmesi. Bitki Koruma Bülteni 41(1/2): 17-24.

Sağır A, Başbağ S (2002) Determination of the effect of wilt disease caused by Verticillium dahliae Kleb. on some physiological and technological properties in cotton. The J. Turkish. Phytopath. 31(1): 1-8.

Sakcı N (2015) Pamukta Solgunluk Hastalığı (Verticillium dahliae Kleb)'nın Tohumun İçeriğine ve Lif Kalitesine Etkisinin Belirlenmesi. Yüksek Lisans Tezi, Dicle Üni. Fen Bil. Enst., Bitki Koruma ABD, Diyarbakır, $65 \mathrm{~s}$

Saydam C, Copçu M (1972) Verticillim wilt in Ege region and its importance on some vegetables. J Turkish Phytopath. 2: 34-40.

Saydam C, Kamal M (1970) Occurrence of Verticillim wilt in Chili, potato and tomato. FAO Plant Protection Bull. 18: 46

Saydam C, Sarıbay A, Öğüt M (1971) Occurance of Verticillium wilt of peach in Turkey. J. Turkish. Phytopath. 2(1): 12-13.

Saydam C, Copçu M (1972) Verticillium wilt of olives in Turkey. J. Turkish. Phytopath. 1(2):45-49.

Saydam C, Delen N, Ercivan S (1973) Verticillium wilt of apricot in the Aegean Region of Turkey. J. Turkish. Phytopath. 2(2): 90-92.

Schnathorst WC (1981) Life cycle and epidemiology of Verticillium, In: Fungal Wilt Diseases of Plants (Eds. Mace ME, Bell AA, Beckman $\mathrm{CH}$ ), Academic Press, Newyork. pp 81-111.

Sezgin E (1985) Pamuk solgunluk hastalığı ile savaşımda kültürel önlemlerin önemi. Bornova Zirai Mücadele Araştırma Yıllığı, İzmir, 3(3): 23-31.

Yelin D, Erşan K (1985) A Research on Yield and Some Technological Characters and Sensivity of Cotton Varieties (G. hirsutum L.) to Verticillium dahliae Kleb. In Kahramanmaraş. J. Turkish Phytopath. 14(3): 96.

Yıldırım M, Sağır A (1999) Pamuk (Gossypium hirsutum I.)'ta kullanılan farklı azot form ve dozlarının solgunluk hastalığı (Verticillium dahliae Kleb.) üzerine etkileri. Türkiye 3. Tarla Bitkileri Kongresi, Kasım 1520, Adana, 274-278.

Yurtsever N (1984) Deneysel İstatistik Metotları. Toprak ve Gübre Araştırma Enstitüsü, Genel Yayın No. 121, Teknik Yayın No. 56, Ankara. 